\title{
The Utilization of ex-Mining Area as an Unique Tourism Object
}

\author{
Nur Aida \\ Faculty of Law \\ Jakarta Islamic University \\ Jakarta, Indonesia \\ nuraidah.dpb@gmail.com
}

\author{
Moh Taufik Husni \\ Faculty of Law \\ Jakarta Islamic University \\ Jakarta, Indonesia \\ taufik_57@yahoo.com
}

\author{
Muhani Jibi \\ Faculty of Law \\ Jakarta Islamic University \\ Jakarta, Indonesia \\ jibimuhani@gmail.com
}

\begin{abstract}
Mining areas have been damaged by mining activities, and structurally damaged so that they can no longer be utilized as a result of mining. However, it can still be done utilization efforts by changing the status of its management into something that can benefit the community and the country. This effort can be done by managing the area of mine land that has been discharged its license management into tourism areas.
\end{abstract}

The former mining area will generally be found in damaged conditions by mining activities. Damage to the area depends on the type of material being mined, how the mine is done as well as the facilities and infrastructure constructed during mining.

The mined material also determines the forms of toxic effects that are caused by materials that qualify harmful to the human and animal, and can result in certain vegetation species can grow. It is due to the deterioration of soil chemical and physical properties and the effects of toxic substances on water in the area.

The improvement of the area is also one of the considerations in the economic field. Since the impact of land damage left by the miners tends to require a greater cost to restore land, especially if during the mining process, it was not done conservation and efforts to restore land conditions as before.

Another effort is to use the former mining area into a tourism area. In case that the land restoration efforts have been successfully overcome by eliminating the factors and harmful elements and the vegetation begins to grow. It can be a place of human activity, a healthy, pollutant free and grow economic activities that benefit both government and society.

Keywords-ex-mining area, utilization, unique tourism

\section{INTRODUCTION}

Like the proverbial said, it's no use crying over spilt, this expression describes how environmental conditions that have been damaged by the exploitation of natural resources without no one considers the consequences of the mining industry.

Although at the beginning of the licensing of mining process, entrepreneurs have fulfilled the requirements to manage the mining business by taking into account the environment and conducting environmental impact analys is (AMDAL). However, the businessman is negligent his obligations and the government does not immediately evaluate the current mining business. Whether it exceeds the established capacity or the mining entrepreneur does exploitation of mining products with the widest possible extent. In fact, the government often knows that there has been environmental damage due to mining activities, because the area are abandoned by the mining companies - the business permit is over-it makes the ex-mining area become damaged.

One source of income for the state for national development is the management of natural resources by the mining industry. The mining industry also opens jobs and prospers the communities around the mining area. However, it leads to new problems of environmental damage and pollution as well. The permanently damaged natural landscapes will not be recovered easily. It needs smart, creative and innovative thinking to restore natural resources that have been damaged to be utilized by the state as a source of income, in order not to become abandoned land because it cannot be utilized any more. One form of business that can be done is to make the ex-mining area as a unique natural tourism area, with modifications and utilize the forms of environmental damage is a tourist attraction that attracts tourists.

This paper discusses the potential utilization of exmining land to become tourism area. The subject covers the extent of the ex-mining area; the problems of ex-mining land in terms of technical, socio-economic, land tenure and legislation; as well as technologies and strategies for reclaiming ex-mining land.

\section{PROBLEM STATEMENTS}

Mining areas that have been damaged by mining activities, and structurally damaged can no longer be utilized. It is as a result of mining activities. However, it can still be done utilization efforts by changing the status of its management into something that can benefit the community and the country. This effort can be done by managing the area of mine land into tourism areas.

How can damaged land, the ex-mining area can still be used as state income and benefit the local community?

\section{DISCUSSION}

Law No. 4 year 2009 concerning mineral and coal mining regulating mining business which includes activities in the 
framework of mineral and coal operations. It covers the general investigation, exploration, feasibility, construction, mining, processing and refining, transportation and sales activities, and post-mining activities. Self-management of the mines can be provided to business entities, cooperatives and individuals.

In the implementation, the management of mining must be done well and correctly including the establishment of mining areas, respect for the holder of land rights, licensing aspects, mining techniques, occupational safety and health, environment, upstream downstream linkages, community development, post-mining closure plans, standardization [1].

Other laws and regulations governing post-mining area management, es pecially the reclamation provisions include:

- Ex-mining land reclamation for expansion of agricultural areas.

- Law no. 11/1967, on the provisions of the principal mining.

- Government Regulation No. 32/1969, regarding the execution of Law no. 11/1967 on the basic provisions of mining.

- PP No. 75/2001, concerning the second amendment of PP. 32/1969.

- Minister Decision PE No. 1211.K/1995 on prevention and prevention of environmental destruction and pollution in general mining activities.

- Decision of Director General of General Mining no. $336 / 1996$ on reclamation guarantees.

Mining is categorized into Energy (Coal, Oil and Gas), Minerals (Gold, Lead, Nickel, Copper, Bau xite) and other Materials (excavation, stone, sand, mica sand, kaolin). Mining techniques are divided into open pit mining and deep hole mining. Mining of excavated materials is deep within the soil and can occur in any excavation activity which results in the presence of deep and deep holes.

In Law no. 11 of 1976 concerning Mining in Indones ia and refers to Government Regulation no. 25 Year 2000, in detail has explained about the authority of the government and the province government as an autonomous region including in the field of mining. There is classification of minerals according to its importance for the government, as follows.

1) Group A, it is a class of strategic mining materials. This means they are important for the defense/security of the State or to guarantee the economy of the country.

Example: all types of coal, petroleum, radioactive material aluminum mine (bauxite), white tin, manganese, iron, and nickel.

2) Group B, it is a vital quarry, which can guarantee the livelihood of many people.

Examples: gold, silver, magnesium, zinc, tungsten, gemstones, mica, and asbestos.

3) Group C, it is excavation material not belonging to class A or B.

\section{A. Impact of Mining Activities}

These mining activities are known to cause loss of biodiversity, degradation of watersheds, landform changes and the release of heavy metals that can enter the aquatic environment [2]. In addition, it also affects the balance of terrestrial ecosystems, decreasing soil productivity and environmental quality. Moreover, the surface of the land becomes irregular so that soil fertility is low and prone to erosion. Therefore, it impact on the carrying capacity of the soil for plants is low. The top soil replaced the soil from the less fertile bottom layer, otherwise the fertile topsoil is in the lower layer. Likewise, the biological population of the soil in the topsoil becomes immersed. Thus, the biological population becomes missing/dead and not working properly [3].

\section{B. Area Handling}

The first step that needs to be done is the mapping of the ex-mining land, which is equipped with land tenure, so that further utilization for agriculture and other businesses can be sustainable.

Land reclamation needs to be done, among others, to increase the carrying capacity and usefulness for biomass production. The determination of the type of land use shall, among other things, be based on ownership status and biophysical conditions of the land, as well as the needs of the community and the local government.

Furthermore, the mine site management requirements are not sufficient only with a feasibility study for the opening of a mining business, but it should also be accompanied by a planning of closure. It includes environmental protection and the mitigation of socio-economic problems. This needs to be one of the requirements in granting mining permits.

For example, tin mining activities in Bangka-Belitung province, it greatly affects the environment and socioeconomic conditions of the community. The results of the evaluation by Puslittanah (1987) show that the area of 198.75 ha which is actually stated to be unsuitable for agriculture is largely underneath, sand, silt, and polluted tailings strands resulting from mining activities. Issues Mining companies are required to be able to return ex-mining land to conditions in accordance with the requirements of land use based on the regional spatial planning [4] [5].

Utilization of ex-mining land, in addition to tourism, is the expansion of agricultural areas. It is also an opportunity to solve food and environmental problems if the physical and chemical elements of the land meet agricultural requirements.

It means, after mining is complete, there must be a transformation of benefits or restore the mined land to the initial conditions, so as to align with the princip le of benefits and sustainable. However, both are difficult to achieve, since generally mine closure planning (including reclamation) is not integrated with mining operations from the beginning until closing, so that post-mining is sues arise.

As we know, mining area and mining operations are relatively large, it began in the mid-1970s. Prior to 1970, mining activities have also been carried out, but still on a relatively small scale. Up to 2009 , of the total land cleared for exploitation permits was 2,205,348 ha, land cleared for mining and infrastructure areas was only 135,000 ha, with a 
total reclaimed area of 33,767.58 ha. Land cleared for mining is not widespread, so after 30 years, the damaged area is relatively narrow at $0.07 \%$ compared to the whole of Indonesia[5].

This means that mining is concentrated in a certain area, but its impact on the region in question is quite dominant.

\section{Restoration}

As we know that ecology is the study of the mutual relationship between living creatures and their environment, while restoration means as an improvement or recovery. So restoration ecology can be interpreted as an application of ecological science that seeks to repair or restore a damaged ecosystem or disturbed so that it can recover or reach an ecosystemapproaching its original condition.

In order to restore the damaged ecosystems, ecological principles and knowledge are essential needed because it is the fundamental principle that must be known to understand the problems of restoring a damaged ecosystem. Fundamentals are like: knowledge of species, community and ecosystem, ecotype, species substitution, interaction between individual species and ecosystemand succession.

Restoring damaged ecosystems aims to:

(1) Protective, in this case,, it improves the stability of the land, accelerates land cover and reduces surface run off and soil erosion,

(2) Productive, leading to more productive soil fertility, so that cultivated crops not only produce timber, but also produce non-timber products (rattan, gums, medicines, fruits and others) that can be utilized by the surrounding community, and

(3) Conservative; it is an activity to help accelerate the occurrence of a natural succession towards the enhancement of the biodiversity of local species; as well as saving and utilizing potentially rare local plant species [6]. The final conditions of rehabilitation can be directed to achieve such conditions before being mined.

In general, the outline of the reclamation phase is as follows: Top soil conservation is a layer of soil that needs to be conserved, because it is most qualified to be a mediu $\mathrm{m}$ for growing plants. Therefore, the environmental impacts of mining resulting from decreases in soil productivity, soil compaction, erosion and sedimentation, soil and landslide movements, disruption to flora and fauna, disruption to the security and health of the population and micro-climate change need to be detailed and so that the ex-mining area becomes a livable area for living creatures, especially for humans who will utilize the land.

\section{Reclamation and Re-vegetation}

Land of Post Coal Mining activities according to the Regulation of the Minister of Energy and Mineral Resources No. 18 of 2008 on Reclamation and Closure of Mining, reclamation is an activity aimed at improving or managing the use of disturbed land as a result of mining business activities in order to be functional and efficient according to their allocation.

Ex-mining land reclamation is actually a mining company's obligation, in accordance with the applicable regulations. However, the implementation is very slow.
According to the Directorate General of Minerals, Coal and Geothermal (2006), only about one-third of the land area is cleared for mines that have been reclaimed, so acceleration of reclamation is necessary. The delay in reclamation of exmining land is caused by various technical and non-technical constraints. These constraints need to be identified first, then find the best solution and easy to implement (practicable), so that these lands can be furthermore used for the welfare of the community.

Reclamation is an effort to repair damaged land as a result of mining business activities, in order to function optimally according to ability. Law No. 4 of 2009 defines reclamation as an attempt to repair or restore damaged land and vegetation in order to function optimally in accordance with its designation. The target of reclamation is to return mining land to conditions similar to the condition before mining [2].

Re-vegetation is an activity of planting post-mining area with selected plants. Re-vegetation begins with planting cover crops and trees, as well as crop maintenance [2]. The success of Re-vegetation on mining land is determined by many aspects such as landscaping, fertility planting area and planting and cultivation. The landscape arrangement is closely related to soil and water conservation aspects as well as the planned use of ex-mining land.

\section{E. Analysis of Supporting Factors to Become Tourism Area}

An area can be developed into a tourist destination, to meet as a tourist destination worth visiting at least there are 3 (three) things that must be developed namely:

\section{There is something to see}

The point is something interesting to see, can be a natural phenomenon, art and culture, or other human creativity.

\section{There is something to buy}

The point is a tourist area should have something interesting and distinctive features that can be purchased by tourists. Local products are offered by the community in hopes other than as something useful for tourists and keepsakes are also able to increase the economic income of people in tourist areas.

3. There is something to do

The point is something activity can be done in that place. At least there are several alternative activities in one tourist area, for example in Goa Cemara beach in addition to enjoy the typical waves, tourists can do various other activities there, for example, participate in the auction of fresh fish freshly brought fishermen, can take shelter under the pine trees with family while lunch with lunch brought, other than that tourists can also shop various handicraft products there. Various alternatives of activities that exist in a tourist area can be selected some are seeded as a point of interest.

The three points above are important things that can be considered to be optimized in tourism management. On the other hand, in the case of the development of a tourist destination area, there are some points to consider by the managers as the principles of development. There are: 
1. The development of tourist areas undertaken at least has been able to compete with existing attractions and similar to other tourist objects elsewhere.

2. The development of tourist areas shall be fixed, unchanged and not moved except from the field of development and construction.

3. Must have adequate facilities and infrastructure and has its own characteristics.

4. The development of the tourist area should be interesting in the general sense (not the subjective understanding) and the touris $m$ awareness of the local community.

5. Understand the characteristics, unique traits and vulnerabilities of objects that have potential to be lifted as attractions.

6. Understand market characteristics (origin, demographics, total expenditure etc.).

7. Seeking significance of relationships that benefit both parties (attractions and markets) as well as the general public and the tourismindustry.

8. Look for the shortcomings and advantages that the object has on the basis of an in-depth assessment based on market, community, industry, and government policy viewpoints.

9. Determine the strategy of maintaining the advantages to keep the object degradation not occur due to tourism exploration.
10. Determine strategies to develop/correct deficiencies in order to meet minimum market standards and requests as well as stakeholders.

11. Develop programs as a consequence of the last two points above.

Some concepts of tourism development is considered true and friendly to the environment (social, natural and cultural) such as sustainable tourismand community-based touris m.

\section{TARGETS AND SOLUTIONS}

The ex-mining area can be used as a tourism area, it is the area that has been tested the quality of environmental support such as the chemical condition and physics of its soil free of harmful toxins, both for humans and animals. The air is free of pollution and dust, soil contours are maintained so that the pattern of river water movements and rain water can flow naturally, so the area is comfortably inhabited and can grow into an economy that provides benefits for the community and government.

\section{REFERENCES}

[1] Sudrajat, 2010.

[2] A. B, "Potensi Jenis Pohon Lokal Cepat Tumbuh untuk Pemulihan Lingkungan Lahan Pascatambang Batubara (Studi Kasus di PT. Singlurus Pratama, Kalimantan Timur)," Universitas Diponegoro, 2012.

[3] Subowo, 2011.

[4] Mulyanto, 2008.

[5] Soelarso, 2008.

[6] Rahmawaty, 2002. 